\title{
SUDDEN SENSORINEURAL HEARING LOSS
}

\section{A case report supporting the immunologic theory}

\author{
Antonio Luiz dos Santos Werneck ${ }^{1}$, Luiz Carlos do Amaral Gurgel2 \\ Laurinda Moura de Mello ${ }^{3}$, Gabriella Queiroz de Albuquerque ${ }^{4}$
}

\begin{abstract}
Sudden sensorineural hearing loss (SSNHL) is one of the autoimmune diseases of the inner ear (AIED), which is characterized by a hearing loss of above 30 decibels in at least three contiguous audiometric frequencies over a time course of 72 hours or shorter. Its cause can be found in only $10 \%$ to $15 \%$ of patients. Histopathologic findings have reported retrograde neuronal degeneration and atrophy of Corti's organ and of the vascular stria. This paper describes a case of a middle-aged female patient undergoing a treatment for hyperthyroidism who developed bilateral SSNHL. The patient was treated with methylprednilisone $(1 \mathrm{mg} / \mathrm{kg} /$ day) for three days with considerable hearing improvement. This treatment was followed by lung and kidney tuberculosis. The immune mechanism of this entity and the possibility of interconnected participation of the antigen type, of an autoimmune disease and of bacterial infection are discussed.
\end{abstract}

KEY WORDS: sudden sensorineural hearing loss, autoimmune disease, autoimmune thyroid disease, tuberculosis.

\section{Surdez neurosensorial súbita: relato de um caso clínico corroborando a teoria auto-imune}

RESUMO - A surdez neurosensorial aguda (SNSA) é uma das doenças auto-imunes do ouvido interno caracterizada pela perda da audição acima de 30 decibéis, em pelo menos 3 freqüências audiométricas contíguas, no período máximo de 3 dias. Sua causa só é definida em 10 a 15\% dos pacientes. Achados histopatológicos demonstram degeneração neuronal retrógrada e atrofia do órgão de Corti e da estria vascular. Relatamos o caso de uma paciente de média idade em tratamento de hipertireoidismo que apresentou SNSA bilateral. A paciente foi tratada com metil-prednisilona ( $1 \mathrm{mg} / \mathrm{kg} / \mathrm{dia}$ ) durante três dias evoluindo para uma melhora considerável da audição. Este tratamento foi seguido de tuberculose pulmonar e renal. Discute-se o mecanismo imunológico desta entidade, e a possibilidade de participação cruzada do tipo antígeno, doença autoimune e infecção bacteriana.

PALAVRAS-CHAVE: surdez neurosensorial aguda, doença auto-imune, doença auto-imune da tireóide, tuberculose.

In 1923, Duke ${ }^{1}$ suggested for the first time that sudden deafness could be related to some allergic phenomenon. In 1979, McCabe $^{2}$ listed a group of diseases which he denominated autoimmune inner ear diseases (AIED). Among these were included sudden sensorineural hearing loss (SSNHL), sudden deafness and Ménière's disease. Satisfactory response of SSNHL to corticosteroids permitted its inclusion in this group. The cochlear channel is situated in the membranous labyrinth of the inner ear. The auditory spiral organ is located in the cochlear channel and it is formed by ciliated neuroepithelial cells and diverse varieties of supporting cells. The penetration of the sound into the inner ear reaches
Corti's organ via the endolymph of the cochlear channel up to the hair cells. This stimulus is conveyed by nerve fibers situated at the base of the hair cells up to the spiral ganglion neurons, where there are about 30,000 afferent neurons. AIED is characterized by retrograde neuronal degeneration, endolymphatic edema, proliferation of fibrous tissue, compression of perilymphatic spaces, in addition to the atrophy of Corti's organ and of the vascular stria ${ }^{3}$. These findings suggest the existence of a simultaneous inflammatory and ischemic vascular process in the inner ear.

SSNHL is a medical emergency case clinically defined as a hearing loss of a minimum of 30 decibels, assessed in at least three audiometric frequencies

\footnotetext{
Serviço de Clínica Médica do Hospital Central do Instituto de Assistência aos Servidores do Estado do Rio de Janeiro (IASERj; Rio de Janeiro RJ, Brasil; ${ }^{1}$ Chefe do Serviço de Neurologia; ${ }^{2}$ Chefe do Serviço de Clínica Médica; ${ }^{3}$ Médica do Serviço de Clínica Médica; ${ }^{4}$ Médica Residente do Serviço de Clínica Médica.
}

Received 28 April 2003, received in final form 16 July 2003. Accepted 20 August 2003.

Dr. Antonio Luiz dos Santos Werneck - Rua João de Barros 137/601 - 22441-100 Rio de Janeiro RJ - Brasil. 
Table 1. Causes of sudden sensorineural hearing loss.

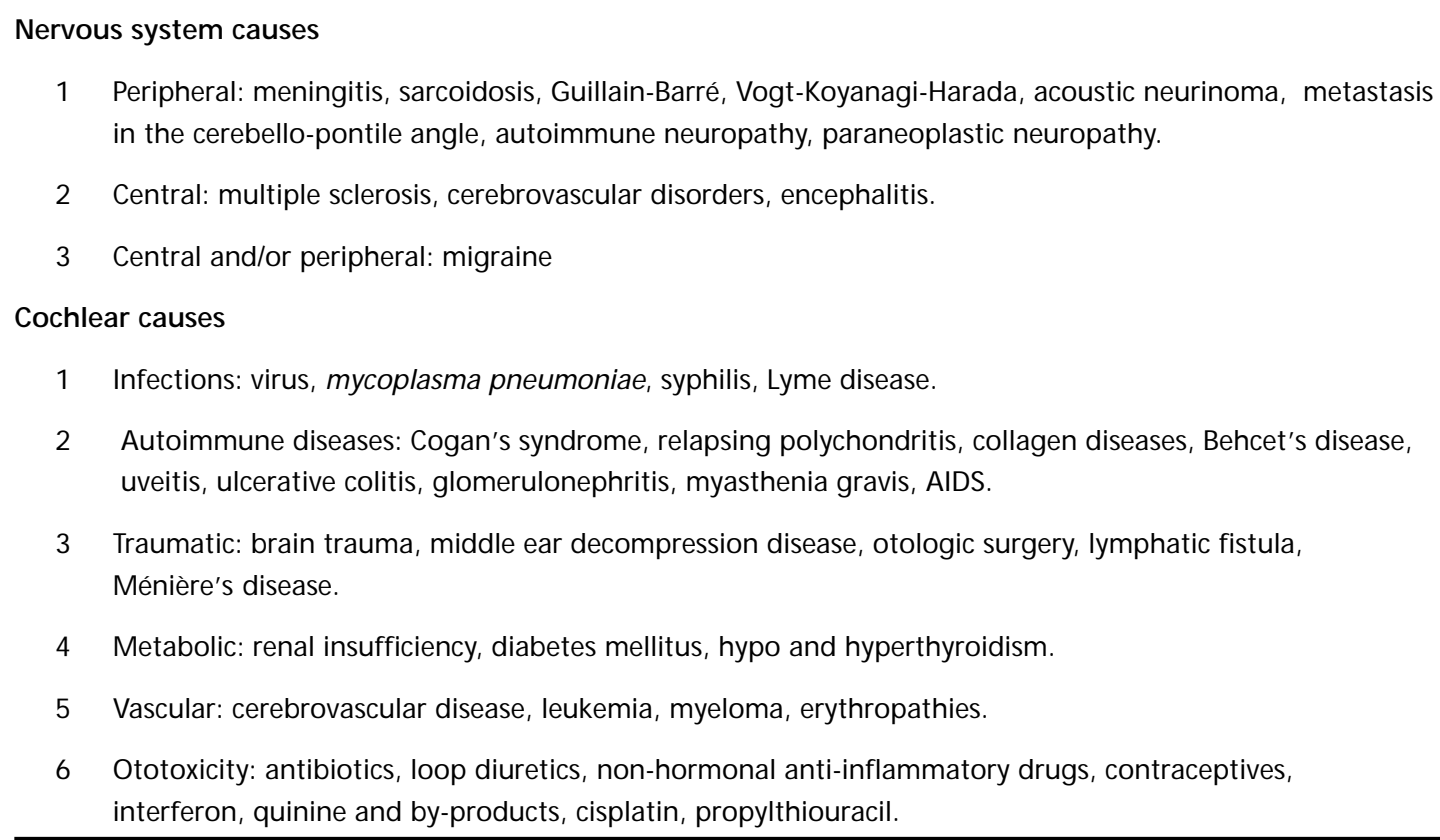

within a period ranging from three hours to three days ${ }^{4}$. The estimated yearly incidence of SSNHL is 5 to 20 cases 100,000 persons ${ }^{5}$. Its cause being known in only $10-15 \%$ of the cases $^{6}$. Table 1 lists the major nervous system and cochlear causes of SSNHL. Young female adults are preferably affected, and the diagnosis is based on clinical criteria and on good response to corticosteroids. Numerous attempts have been made to develop assays to detect serum markers that may help to confirm the diagnosis, which include: erytrocyte sedimentation rate, eletrophoresis of immunoglobulins, complements $(\mathrm{C} 3, \mathrm{C} 4, \mathrm{CH} 50$, $\mathrm{Clq}$ ), anticollagen antibodies, rheumatoid factor, immunophenotype of lymphocytes (CD4+, CD8+, CD4+/CD8+), Western-Blot for protein-70 sensitive to heat shock, antiviral antibodies and PCR, bacterial tests and tests for fungi.

A case of SSNHL is described with particular aspects not yet referred in the literature, which supports the immunologic theory.

\section{CASE}

A woman, born in Austin/R, Brazil, 52 years old was hospitalized on August $8^{\text {th }} 2002$, presenting weight loss (14 kg in three months), anorexia, asthenia and severe anemia (hematocrit: 19\%). The patient had underwent a treatment for hyperthyroidism for at least four years, with the use of $200 \mathrm{mg} /$ day of propylthiouracil for about eight months. After eight days of hospitalization, the patient presented coughing with mucoid expectoration, dyspnea and constant fever during three days (average 39-40 degrees). In this phase we have opted for an increase in the dosage of propylthiouracil to $600 \mathrm{mg} / \mathrm{day}$, as there were high rates of T3 $(2.85 \mathrm{ng} / \mathrm{ml}), \mathrm{T} 4(17.48 \mathrm{ng} / \mathrm{dl})$ and $\mathrm{TSH}<0.01 \mathrm{n} \mathrm{IU} / \mathrm{ml}$. Scintigraphy of the thyroid showed a moderate increase of the volume of the gland, especially in the right lobe, with diffuse and heterogeneous ecotexture. Physical examination showed: thinness, paleness and dehydrated patient; bilateral and symmetrical exophtalmia with lid lag; increased thyroid volume with irregular surface and hardened consistence. Search for acid-fast, anti-HTL $\mathrm{VI} / \mathrm{II}$-Elisa and indicators for hepatitis B and C were negative. Protein electrophoresis without anomalous fractions; non-reagent ANF; complement $\mathrm{CH} 50, \mathrm{C} 3$ and $\mathrm{C} 4$, normal; negative LF cells; ferritin: $20 \mathrm{ng} / \mathrm{ml}$, total transferrin: $200 \mathrm{mg} / \mathrm{ml}$; iron linkage capacity: 250.3; reticulocyte count $1 \mathrm{IU} / \mathrm{ml}$; CEA: 3ng/ml; antigens Ca 19-9: $13 \mathrm{IU} / \mathrm{ml}$ and CA $125: 11 \mathrm{IU} / \mathrm{ml}$.

Around eleven days after hospitalization, the patient presented sudden, bilateral hearing loss. The results of otorhinolaryngological exams were normal, with the exception of deafness. Audiometry (Fig 1) showed sensorineural hearing loss from intense to severe, with an absence of response in $8 \mathrm{KHz}$ in both ears. In the left ear, aerial conveyance was of $61.6 \mathrm{~dB}$, and of $63.3 \mathrm{~dB}$ in the right ear. Bone conveyance was at 51.6 in the left ear, while in the right ear it was of $56.6 \mathrm{~dB}$. S.R.T. was of $60 \mathrm{~dB}$ in the left ear and of $70 \mathrm{~dB}$ in the right ear. There was a discrimination of $28 \%$ with $100 \mathrm{~dB}$ in the left year, compared with $36 \%$ and $100 \mathrm{~dB}$ in the right ear. Tympanometry demonstrated a curve of the " $\mathrm{A}$ " bilateral type, with an absence of the contralateral stapedial reflex in both ears. There was no response to the interruption of propylthiouracil for six days. Methylprednilosone was then administered at $1 \mathrm{mg} /$ $\mathrm{kg} /$ day to the patient for three days, followed by $60 \mathrm{mg} /$ 


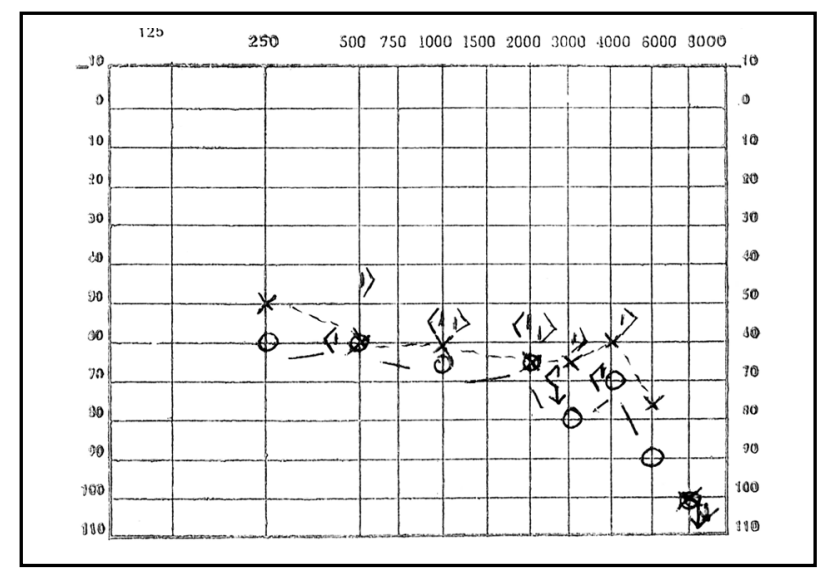

Fig 1. Sensorineural hearing loss from intense to severe, with an absence of response in $8 \mathrm{KHz}$ in both ears. In the left ear aerial conveyance was of $61.6 \mathrm{~dB}$, and of $63.3 \mathrm{~dB}$ in the rigth ear. Bone conveyance was at 51.6 in the left ear abd of $56.6 \mathrm{~dB}$ in the rigth ear. SRT was of $60 \mathrm{~dB}$ in the left ear of $70 \mathrm{~dB}$ in th ear.

day for 6 days and $30 \mathrm{mg} /$ day for eight days. Ten days after the introduction of this scheme there was complete subjective regression of deafness.

Approximately 20 days later the patient presented fever and dry cough. Thoracic X-ray showed diffuse focuses in both lungs, indicative of miliary tuberculosis. Blood test showed: creatinine - $1.9 \mathrm{mg} / \mathrm{dl}$ and urea $-121 \mathrm{mg} / \mathrm{dl}$. Therapeutic evidence confirmed the diagnosis of lung and kidney tuberculosis.

\section{DISCUSSION}

Maguchi et al. ${ }^{7}$ have reported one case of hyperthyroidism associated to SSNHL in a 36-year old woman treated with propylthiouracil, where a decrease of the complement level, of the high levels of $M$ immunoglobulin and of the antineutrophil cytoplasmic antibody (ANCA) reactive to myeloperoxidase (MPOANCA) could be demonstrated. There was an amelioration of deafness after the withdrawal of propylthiouracil. Until then, no case of SSNHL associated with MPOANCA had been reported, which led the authors to suggest that microvascular disease might be related to SSNHL pathophysiology. Fong et al. ${ }^{8}$ reported polyarthritis, leukocytosis, hepatotoxicity, normocytic normochromic anemia, high fever, cutaneous vasculitis and SSNHL in one patient using propylthiouracil, evolving to complete remission after its withdrawal.

In the assessment of the case described, we have initially thought of ototoxic secondary effect related to the use of propylthiouracil, since there are reports of adverse reactions in 1 to $5 \%$ of the patients who have used this substance. However, there was no response to the interruption of medication, the pa- tient being asymptomatic only after using methylprednilosone (1g/day) for three days. We believe this treatment facilitated the occurrence of miliary tuberculosis.

Several studies associate viral infection, vasculitis and immunological factors to models of experimental labirynthitis in $\mathrm{SSNHL}^{9,10}$. The presence of infections by herpesvirus is attributed to about $70 \%$ of the cases ${ }^{11}$. In such cases, the infection by virus would provokesome type of vascular functional disturbance which would be followed by a relevant immunological response inside the inner ear. The consequence would be the production of bone-fiber matrix, responsible for irreversible cochlear lesion and retrograde neuronal degeneration. These alterations have been described in diverse autoimmune diseases, such as myasthenia gravis, systemic lupus erithematosus (SLE), Guillain-Barré, Vogt-Koyanagi-Harada, Graves' disease, Wegener's granulomatosis and Cogan's syndrome ${ }^{9,12-14}$. It seems possible that hyperthyroidism may have some participation in the immunopathogeny of SSNHL. It is known that polymorphism is one of the characteristics of the HLA molecules, being some of its peptides dependent on individual alleles. Autoimmune diseases such as hyperthyroidism, myastenia gravis, and LSE suffer the influence of inherited alleles capable of playing a part in the formation of sometype of self-antigen. It is also possible to ascribe some vascular participation to the physiopathology of SSNHL. Some case reports associated migraine with fluctuating low-frequency hearing loss and sudden, unilateral hearing loss ${ }^{15}$. Studies carried out with patients with autoimmune diseases of the SLE and periarteritis nodosa (PAN) types have shown the presence of cochlear fibrosis and ossification of the inner ear, findings which are characteristic of vascular disease $^{16}$. Atrophy of Corti's organ and of the vascular stria, ossification of the inner ear, degeneration of the vascular elastic membrane with or without associated vasculitis and, still, retrograde neuronal degeneration have also been reported ${ }^{16,17}$. These findings suggest the existence of a simultaneity between the inflammatory process and the ischemic involvement in the SSNHL.

The presence of antiendothelial antibodies in patients with SSNHL indicates the participation of serologic markers of vasculitis, although some studies with antinuclear antibodies, rheumatoid factor, antimitochondrial antibodies, smooth anti-fiber, antisarcolemma, antilaminine and anticollagen II have been controversial. Besides that, SSNHL may be the initial manifestation of Sjögren's syndrome, SLE, 
Wegener's granulomatosis, PAN and Cogan's syndrome ${ }^{18,19}$.

The existence of autoantibodies against inner ear antigens implies an autoimmune pathogenesis of SSNHL. Analysis through immunological assay of the Western-Blot type demonstrated the presence of a self-antibody anti-68Kd in the patients' serum with $\mathrm{SSNH}^{20}$. The existence of a connection between the antigen 68 kilodalton with protein-70 sensitive to heat shock (HSP-70) has already been observed ${ }^{20}$. This protein that acts in cellular protection is present in the blood vessel, in Corti's organ and in the brain. Boulassel et al. ${ }^{21}$ carried out a study on self-antibodies against proteins of the inner ear in animal models which have been found in patients with AIED. It has been demonstrated that proteins of 30,42 and 68 kilodalton are part of the periphery of the main protein of PO myelin, and of the beta-actinic protein. PO protein appears exclusively in the Schwann's cells of the peripheral nervous system, in the spiral ganglion and in Corti's organ, whereas beta-actinic protein may be observed in the mechanic-sensorial cells of the ciliary support. Beta-actinic protein has been observed with its modified composition in patients with deafness and peripheral vestibular syndrome. Such de-structuring may result in disintegration of structural cells of the inner ear which are responsible for the transformation of mechanic into electrochemical stimuli. Thus, one can also believe that antibodies against beta-actinic protein may lead to vestibular-auditory disturbances. Otherwise, anti-PO antibodies have been reported in patients affected with Guillain-Barré ${ }^{22}$. Hypoacusis symptom has been reported in these patients although no antibodies against PO and beta-actinic proteins have been found.

It is important to point out the participation of corticosteroids in emergency therapeutics. Receptors of corticosteroids in cochlear and vestibular tissues of animal models have been identified ${ }^{23}$, which have led to the treatment of AIED with intra-tympanic or systemic corticosteroids. High levels of C3, C3bc, C4e, $\mathrm{Clq}$ have been reported in patients with $\mathrm{SSNHL}^{24}$, which may identify patients that respond to antiinflammatory drugs of the corticosteroid type. The main action of corticosteroids in SSNHL would be the blockage in the production of antibodies, of interleukyns (IL, IL-2, IL-3, IL-4<IL-5, IL-6, IL), of TNFAlfa and of gamma-interferon and the reduction of the lymphoproliferative process ${ }^{9}$. In spite of immunological investigation being capable of accurately identifying patients with SSNHL, candidates to corticotherapy, temporal clinic criteria and audiometry are the main patterns to be observed in the immediate treatment of this entity.

We have not found any reference to a possible association between SSNHL and miliary tuberculosis. It seems possible that the occurrence of an immunological response in the endolymphatic sacculus provoked by the presence of the Koch's bacillus, so far clinically latent, might have triggered some type of autoimmune response. Alterations have been reported in T cell subpopulations in patients with SSNHL associated to infection by Mycoplasma pneumoniae or virus, when it was observed an increase in the memory T cells (CD4CD5RO) and a decrease of naive T cells (CD4CD45RA) ${ }^{14}$. It is possible that a bacterial agent might provoke sufficient antigenic stimulus to transform naive $T$ cells into memory $T$ cells. The activation of the then latent microorganism would stimulate the presence of memoryT-cells with the consequential autoimmune response in the inner ear. The result of this immunological inflammatory response would bethe degeneration of Corti's organ, of the blood vessel and the spiral ganglion.

It is also known that the antibodies that react against antigens of inner ear may appear in interconnected reaction with bacterial or viral infections, or in the event of tissular destruction. Extracts taken from the inner ear of animal models with proteins of various molecular sizes (14 to 200 kilodalton) have reacted positively to Western-Blot when confronted with the serum from patients with SSNHL ${ }^{21}$.

In summary, the immune mechanisms that are operative in the genesis of SSNHL are not fully understood. The case reported suggests a link between bacterial infection, hyperthyroidism and autoimmune reactions to the abnormal expression of autoantigens on inner ear cells.

\section{REFERENCES}

1 DukeWW.Ménière'ssyndromecaused by allergy.JAMA 1923;81:2179-2181

2. McCabeBF. Autoimmunesensorineural hearing loss. Ann Otol Rhinol Laryngol 1979;88:585-589.

3. Schuknecht $\mathrm{H}$. Ear pathology in autoimmune disease. Adv Oto Rhinolaryngol 1991;45:50-70.

4. Wilson WR, Byl FM, Laird N. The efficacy of steroids in the treatment of idiopathic sudden hearing loss. A double-blind clinical study. Arch Otorhinolaryngol 1980;106:772-776

5. Byl FMJr. Sudden hearing loss: eigth years' experience and suggested prognosis table. Larynngoscope 1984:94:647-661.

6. Mattox DE, Lyles CA. Idiopathic sudden sensorineural hearing loss. Am J Otol 1999;20:587-595.

7. Maguchi S, Satoshi F, Chida E, Terayama Y. Myeloperoxidaseantineutrophil cytoplasmic antibody-associated sensorineural hearing loss. Auris Nasus Larynx 2001;28 (Suppl 1); S103-S106.

8. Fong PC, Pun KK, Tai YT, Yeung RT. Propylthiouracil hypersensivity with circumstantial evidencefor drug-induced reversiblesensorineural deafness. Horm Res 1991;35:132-136.

9. García-Berrocal JR, Ramirez-Camacho R. Sudden sensorineural hearing loss. Ann Otol Rhinol Laryngol 2002;111:989-97 
10. Oldstone MBA. Virus-induced autoimmunity: molecular mimicry as a routeto autoimmunedisease. J Autoimmune 1989;(Suppl 2):S187-S194.

11. Wilson WR. The relationship of the herpesvirus family to sudden hearing loss: a prospective clinical study and literature review. Laryngoscope 1986;96:870-877.

12. Ammar-Khodia A. Autoimmune deafness and myasthenia. Rev Laryngol Otol Rhino (Bord). 1991;112:161-163.

13. Bicknell JM, Holland JV. Neurologic manifestations of Cogan's syndrome. Neurology 1978;28:278-280.

14. García Berrocal JR, Ramírez-Camacho R, Portero F, Vargas JA. Role of viral and M ycoplasma pneumoniae infection in idiopathic sudden sensorineural hearing loss. Acta Otolaryngol (Stockh ) 2000;120:835-839.

15. Lee $H$, Whitman GT, Lim JG, et al. Hearing symptoms in migrainous infarction. Arch Neurol 2003;60:113-116.

16. Yoon TH, Paparella MM, Schaschern PA. Systemic vasculitis: a temporal bone histopathologic study. Laryngoscope 1989;99:600-609.

17. Yoon TH, Paparella MM, Schaschern PA, Alleva M. Histopathology of sudden hearing loss. Laryngoscope 1990:1990;100:707-715.
18. Lunardi C, Bason C, Leandri M, et al. A utoantibodies to inner ear and endothelial antigens in Cogan's syndrome. Lancet 2002;360:915-921.

19. Harris JP, Sharp PA. Inner ear autoantibodies in patients with rapidly progressivesensorineural hearing loss. Laryngoscope 1990;100:516-524.

20. BillingsPB, Keithley EM, HarrisJP. Evidencelinking the 68 kilodalton antigen identified in progressive sensorineural hearing loss patient sera with heat shock protein 70. Ann Otol Rhino Laryngol 1995;104:181-188.

21. Boulassel MR, Deggouji N, Tomasi JP, Gersdorff M. Inner ear autoantibodies and their targets in patients with autoimmune inner ear diseases. Arch Otolaryngol 2001;121:28-34.

22. Ben-Joulloun-Dellagi S, Dellagi K, Burger D, et al. Chidhood peripheral neuropathy with autoantibodies to myelin glycoprotein PO. Ann Neurol 1992;32:700-702.

23. Rarey KE, Curtis LM. Receptors for glucocorticoids in thehuman inner ear. Otolaryngol Head Neck Surg 1996;115:38-41.

24. Nordang L, Laurent C, Mollness TE. Complement activation in sudden deafness. Arch Otolaryngol Head Neck Surg 1988;124:633-636. 